\title{
Content of nutrients and energy in pasture vegetation and their apparent digestibility in Old Kladruber horses
}

\author{
Eva Straková1, Pavel Suchý ${ }^{2}$ \\ ${ }^{1}$ University of Veterinary and Pharmaceutical Sciences Brno, Faculty of Veterinary Hygiene and Ecology, \\ Department of Animal Nutrition, ${ }^{2}$ Department of Animal Husbandry and Animal Hygiene, \\ Brno, Czech Republic \\ Received April 23, 2012 \\ Accepted October 23, 2012
}

\begin{abstract}
This study focuses on the determination of apparent digestibility of pasture vegetation nutrients in horses of the Old Kladruber breed through a balance indicator method (determination of acid insoluble ash). When evaluating the nitrogenous substances, their determination was based on the content of pure protein (sum of amino acids) which is more accurate than crude protein. There were differences in the chemical composition of dry matter from pasture vegetation and horse excrements. Regarding crude fat, crude fibre, acid detergent fibre, neutral detergent fibre, acid detergent lignin, ash, $\mathrm{P}$ and $\mathrm{Mg}$, the average values in dry matter of horse excrements were significantly $(P \leq 0.01)$ higher; on the contrary, we found significantly $(P \leq 0.01)$ lower mean values of nitrogen-free extract, organic matter and $\mathrm{Ca}$ in the dry mass of pasture grass. The highest coefficient of apparent digestibility for organic nutrients was determined in the nitrogenfree extract $(73 \%)$ followed with organic matter $(71 \%)$, pure protein $(68 \%)$, crude protein $(65 \%)$ and crude fat $(61 \%)$. In case of fibre and its fractions, the apparent digestibility coefficients decreased as follows: crude fibre (66\%), neutral detergent fibre $(66 \%)$, acid detergent fibre $(63 \%)$ and acid detergent lignin (42\%). Significantly lower values were determined for coefficients of apparent digestibility for minerals $\mathrm{P}(16 \%)$ and $\mathrm{Mg}(50 \%)$, which highlights the need for their regular supplementation in horses on pasture. This study extends the current state of knowledge regarding the apparent digestibility of pasture vegetation which is a prerequisite for optimal nutrition of horses.
\end{abstract}

Equine nutrition, grazing, forage, chemical composition, excrements, indicator method

One of the important internal factors contributing to the welfare of horses is genetics, as reported by Vostrý et al. (2012). One of the important external factors is nutrition, especially the nutritional value of feed and digestibility of basic nutrients. Currently, there are several methods for determining the apparent digestibility of feed and feeding rations in horses. Generally, most of them are in vivo methods based on the use of external or internal markers. Indigestible detergent fibre, acid-detergent lignin and n-alkanes can be used as internal markers (Miraglia et al. 1999). A proven and most widely used method for determining the apparent digestibility can be considered the method of determining the digestibility using the marker in the form of acid insoluble ash as presented by Sales and Janssens (2003) or Zeyner et al. (2003). Forage digestibility is influenced by many factors such as forage botanical composition (Pearson et al. 2006), forage mechanical processing (Drogoul et al. 2000), forage preserving (Miyaji et al. 2008) and forage quality (Miyaji et al. 2011), fibre content and especially energy content in a feeding ration (Homolka et al. 1995). Varloud et al. (2004) proposed that the energy content significantly influences the digestibility of structural carbohydrates. The balance result is also affected by the method used for assessing the total digestibility, especially by the selected marker.

The aim of this study was to determine the apparent digestibility of nutrients and energy with regard to the feeding ration in horses of the Old Kladruber breed based on the total daily intake of pasture vegetation. 
Our experiment was based on the scientific hypothesis that the digestibility of monitored nutrients contained in pasture vegetation would be higher compared to the digestibility of nutrients contained in processed feeds, especially after their conservation or heat processing during which individual nutrients, mainly proteins, are denatured, which results in their lower digestibility. The results achieved will significantly contribute to balancing nutrients and energy in feed rations for horses.

\section{Materials and Methods}

During the first week of June 2011, sampling of pasture vegetation and faeces was carried out within one pasture area of 6 ha where 33 two-year-old Old Kladruber horses were grazed. Pasture vegetation samples were taken from 10 sites within the pasture area, each sample from the area of approximately $1 \mathrm{~m}^{2}$ at the amount of about $1 \mathrm{~kg}$ of fresh matter, without the individual identification of horses. Similarly, 10 samples of fresh faeces in roughly the same amount were collected from the same pasture area to which the animals had been adapted.

From the botanical point of view, the pasture vegetation quality can be assessed as very high with the prevalence of grasses such as cock's foot (Dactylis glomerata), meadow foxtail (Alopecurus pratensis), red fescue (Festuca rubra), meadow fescue (Festuca pratensis), commonmeadow grass (Poa pratensis). Tall oatgrass (Arrhenatherum elatius), couch grass (Agropyrum repens), perennial ryegrass (Lolium perenne) and creeping bentgrass (Agrostis stolonifera) were less frequent. As the pasture stands were regularly treated with herbicides, the incidence of dicotyledonous plant species like shepherd's purse (Capsella bursa pastoris), sticky willy (Galium aparine), white clover (Trifolium repens), dandelion (Taraxacum officinale) or lawndaisy (Bellis perennis) was very low. Sporadically, we identified representatives of the buttercup (Ranunculus) and sorrel (Rumex) genus.

In the pasture vegetation and faeces, we determined the content of dry matter, nitrogen (N), amino acids (AA), fat, crude fibre, neutral-detergent fibre (NDF), acid-detergent fibre (ADF), acid-detergent lignin (ADL) and gross energy (GE).

Dry matter was determined by weight upon drying the sample at $105{ }^{\circ} \mathrm{C}$ under prescribed conditions. The content of nitrogenous substances (crude protein) was calculated from the nitrogen content, determined by Kjeldahl method using the Buchi analyzer (company Centec automatika, Czech Republic), multiplied by the coefficient of 6.25. The amino acid content was determined after acid hydrolysis by $6 \mathrm{~N} \mathrm{HCl} \mathrm{at} 110{ }^{\circ} \mathrm{C}$ for $24 \mathrm{~h}$ using the automatic amino acid analyzer AAA 400 (company INGOS, Czech Republic) on the basis of colour reaction between amino acids and an oxidizing agent (ninhydrin). The analysis of amino acids served for determining the pure protein which covers $\Sigma$ AA (Asp, Thr, Ser, Glu, Pro, Gly, Ala, Val, Met, Ile, Leu, Tyr, Phe, His, Lys and Arg). Fat was determined by the device ANKOM ${ }^{\mathrm{XT10}}$ Fat Analyzer (company O.K. SERVIS BioPro, Czech Republic). Gross fibre, acid-detergent fibre, acid-detergent lignin and neutral-detergent fibre were determined by the device ANKOM ${ }^{220}$ fibre Analyzer (company O.K. SERVIS BioPro, Czech Republic).

Ash was determined by weight after the sample incineration at $550{ }^{\circ} \mathrm{C}$ under prescribed conditions. Calcium, phosphorus and magnesium were determined through incinerating and leaching the sample by extraction and subsequent titration.

Then we calculated the nitrogen-free extract and organic matter content. Regarding minerals, we determined calcium, phosphorus and magnesium. The apparent digestibility of nutrients and energy was determined using the indicator method (acid-insoluble ash) from the pasture vegetation nutrients and faeces as recalculated to $100 \%$ dry matter.

The results achieved were processed by mathematical-statistical methods involving the statistical program Unistat 5.6. We evaluated average values and their differences through a multiple comparison using the test Tukey-HSD at significance levels of $P \leq 0.01$ and $P \leq 0.05$. Each indicator was presented by its average value (x) and standard deviation $( \pm \mathrm{SD})$.

\section{Results}

In this work, we present the results of determining the apparent digestibility of pasture vegetation nutrients and energy in Old Kladruber horses. Analyses of pasture vegetation samples and freshly collected faeces were conducted prior to the actual determination of digestibility coefficients. The average dry matter was $425.5 \mathrm{~g} / \mathrm{kg}$ and $217.8 \mathrm{~g} / \mathrm{kg}$ for the pasture vegetation and excrements, respectively. Results of dry matter chemical analyses concerning pasture vegetation and excrements are shown in Table 1.

Regarding nitrogenous compounds such as crude protein $(\mathrm{N} \times 6.25)$, we also stated pure protein due to a very low informative value of crude protein with respect to the nutrition of monogastric animals although this indicator is still used. For the pure protein we considered the sum of all the amino acids $(\Sigma \mathrm{AA} \mathrm{g} / \mathrm{kg})$ in the feed which represent the real feed protein in 
Table 1. Average content of single nutrients in the dry matter of pasture vegetation and excrements in horses.

\begin{tabular}{lcc}
\hline $\begin{array}{l}\text { Component } \\
(\mathrm{g} / \mathrm{kg})\end{array}$ & $\begin{array}{c}\text { Pasture vegetation } \\
(\mathrm{x} \pm \mathrm{SD})\end{array}$ & $\begin{array}{c}\text { Excrement } \\
(\mathrm{x} \pm \mathrm{SD})\end{array}$ \\
\hline Crude protein & $68.67 \pm 15.376$ & $75.75 \pm 14.895$ \\
Pure protein & $51.48 \pm 13.312$ & $50.60 \pm 10.438$ \\
Crude fat & $20.79^{\mathrm{A}} \pm 3.422$ & $25.80^{\mathrm{B}} \pm 3.191^{\mathrm{B}}$ \\
Crude fibre & $348.94^{\mathrm{A}} \pm 19.287$ & $387.94^{\mathrm{B}} \pm 17.260$ \\
ADF & $432.49^{\mathrm{A}} \pm 15.821$ & $530.28^{\mathrm{B}} \pm 25.395$ \\
$\mathrm{NDF}$ & $672.47^{\mathrm{A}} \pm 25.531$ & $756.55^{\mathrm{B}} \pm 24.095$ \\
ADL & $80.408^{\mathrm{A}} \pm 6.225$ & $152.390^{\mathrm{B}} \pm 9.031$ \\
Nitrogen-free extract & $501.61^{\mathrm{A}^{*}} \pm 29.699$ & $438.77^{\mathrm{B}} \pm 15.510$ \\
Organic matter & $940.01^{\mathrm{A}} \pm 6.829$ & $905.15^{\mathrm{B}} \pm 8.449$ \\
Ash & $59.99^{\mathrm{A}} \pm 6.829$ & $94.85^{\mathrm{B}} \pm 8.449$ \\
Ca & $5.25^{\mathrm{A}} \pm 0.893$ & $3.85^{\mathrm{B}} \pm 0.635$ \\
P & $1.44^{\mathrm{A}} \pm 0.283$ & $3.94^{\mathrm{B}} \pm 0.701$ \\
Mg & $1.51 \pm 0.551$ & $2.18 \pm 0.464$ \\
Gross energy $(\mathrm{MJ} / \mathrm{kg})$ & $18.20^{\mathrm{A}} \pm 0.228$ & $18.59^{\mathrm{B}} \pm 0.298$ \\
\hline
\end{tabular}

${ }^{\mathrm{AB}} P \leq 0.01, \mathrm{ADF}$ - acid detergent fibre, NDF - neutral detergent fibre, $\mathrm{ADL}$ - acid detergent lignin, $\mathrm{SD}$ - standard deviation

Table 2. Apparent digestibility coefficients of pasture vegetation nutrients and energy in horses.

\begin{tabular}{lc}
\hline Component & Digestibility coefficient $(\% \pm \mathrm{SD})$ \\
\hline Crude protein & $64.62 \pm 13.575$ \\
Pure protein & $67.72 \pm 14.050$ \\
Crude fat & $61.04 \pm 11.072$ \\
Crude fibre & $66.17 \pm 5.186$ \\
ADF & $62.67 \pm 6.180$ \\
NDF & $65.70 \pm 5.912$ \\
ADL & $42.24 \pm 9.441$ \\
Nitrogen-free extract & $73.09 \pm 6.020$ \\
Organic matter & $70.60 \pm 5.290$ \\
Ash & $52.70 \pm 5.912$ \\
Ca & $77.64 \pm 3.829$ \\
P & $16.47 \pm 13.013$ \\
Mg & $49.91 \pm 22.678$ \\
Gross energy & $68.82 \pm 5.522$ \\
\hline
\end{tabular}

ADF - acid detergent fibre, NDF - neutral detergent fibre, $\mathrm{ADL}$ - acid detergent lignin, $\mathrm{SD}$ - standard deviation coefficients further decreased in the following order: organic matter, pure protein, crude protein and crude fat. Regarding fibre and its fractions, apparent qualitative as well as quantitative terms. The term "pure protein" in Table 1 means average values $\Sigma$ AA (Asp, Thr, Ser, Glu, Pro, Gly, Ala, Val, Met, Ile, Leu, Tyr, Phe, His, Lys and Arg). As documented in Table 1, a great disproportion considering the values of crude protein (pure protein) is also highlighted by their values of $68.67 \mathrm{~g} / \mathrm{kg}(51.48 \mathrm{~g} / \mathrm{kg})$ and $75.75 \mathrm{~g} / \mathrm{kg} \quad(50.60 \mathrm{~g} / \mathrm{kg}) \quad$ in the pasture vegetation and excrements, respectively. From this perspective, the value of crude protein significantly underestimates the actual protein content in feeds.

With regard to the majority of monitored indicators, i.e. crude protein, crude fat, crude fibre, acid-detergent fibre (ADF), neutral-detergent fibre (NDF), acid-detergent lignin (ADL), ash, $\mathrm{P}$ and $\mathrm{Mg}$, their mean values in the excrement dry matter were higher than in the dry matter of pasture vegetation. Average values of the tested indicators were highly significantly different $(P \leq 0.01)$ except for crude protein.

As regards pure protein, nitrogenfree extract, organic matter and $\mathrm{Ca}$, the average values in pasture forage dry matter were significantly $(P \leq 0.01)$ higher compared to excrements, except for pure protein (Table 1). Results of analysis of the pasture vegetation and excrement samples using the balance indicator method (acid-insoluble ash) were taken to calculate the digestibility of single pasture vegetation nutrients and energy (Table 2). It is evident from the results that organic nutrients of pasture vegetation show higher digestibility compared to mineral substances. The highest digestibility coefficient was determined for the nitrogen-free extract; digestibility 
digestibility coefficients of single nutrients decreased in this order: crude fibre, NDF, ADF and ADL.

Relatively high digestibility was found also with regard to GE of pasture vegetation from which the digestible energy value of $12.525 \mathrm{MJ} / \mathrm{kg}$ of dry matter $(5.668 \mathrm{MJ} / \mathrm{kg}$ of fresh green forage) was determined. Determined coefficients for apparent digestibility of mineral substances including total ash were significantly lower. Regarding minerals, relatively high digestibility was observed for calcium; in contrast, very low digestibility was found for phosphorus. These results are presented in Table 2.

\section{Discussion}

It follows from the obtained results that pasture vegetation is nutritionally suitable food for horses in terms of its botanical and nutrient composition. Balance digestibility in horses was determined by Homolka et al. (1995). For the feeding ration, the composition of which is closest to the nutrient content in pasture stands that we examined, they stated the apparent digestibility of dry matter $(57 \%)$, organic matter $(60 \%)$, gross energy $(58 \%)$, crude protein (57\%), fat (49\%), fibre (49\%) and nitrogen-free extractives (NFE, 67\%). Miraglia et al. (1999) pointed out the differences in the apparent digestibility in horses, using a range of internal markers. When using acid-insoluble ash as a marker, they came to the following coefficients of apparent digestibility: organic matter (63-66\%), gross energy (61-65\%), crude fibre (40-42\%), crude protein (66-70\%), acid-detergent fibre (ADF, 42$49 \%$ ), neutral-detergent fibre (NDF, 48-54\%) and nitrogen-free extract (73-76\%). For a high-quality diet, Miyaji at al. (2011) determined the apparent digestibility coefficients: organic matter (0.574-0.587), crude protein (0.514-0.543), NDF (0.549-0.557), and ADF (0.511-0.519). As regards diets based on $85 \%$ share of meadow hay in light, heavy, pregnant and lactating mares, Martin-Rosset et al. (1990) determined the apparent digestibility coefficients for ad libitum feeding: organic matter (52-57\%), crude protein (54-60\%), crude fibre (39-43\%) and gross energy (49-53\%). Peiretti et al. (2006) studied the apparent digestibility of hay in horses and determined apparent digestibility coefficients in a range of values $(56-70 \%)$, gross energy $(55-67 \%)$ and crude protein $(58-63 \%)$.

In terms of digestibility, we determined a higher coefficient of apparent digestibility for pure protein $(68 \%)$ compared to crude protein $(65 \%)$.

Markedly lower apparent digestibility coefficients of crude protein were indicated by Homolka et al. (1995) and Miyaji et al. (2011) whereas Peiretti et al. (2006) reported slightly lower digestibility coefficients for crude protein. Our results of determination of the apparent digestibility coefficients for crude protein correspond to the results published by Miraglia et al. (1999). Lower values for crude protein digestibility reported by cited authors may be due to the composition of feed rations based on hay or otherwise thermally treated feed where their lower digestibility is also caused by the influence of thermal protein denaturation. As stated by the authors cited, a relatively high digestibility relates to organic matter. Our results roughly correspond to the apparent digestibility coefficients in horses as reported by Miraglia et al. (1999) or Peiretti et al. (2006). The high value of apparent digestibility that we determined for the pasture vegetation is closely associated with the high digestibility of other organic nutrients. The highest value of the apparent digestibility coefficient was determined for the nitrogen-free extract which corresponds also to the results reported in horses by Homolka et al. (1999) and confirms to the digestibility coefficient mentioned for the nitrogen-free extract by Miraglia et al. (1999). Relatively large differences in digestibility in horses are reported for the crude fibre and individual fibre fractions. Most authors such as Miraglia et al. (1999), Miyaji et al. (2011) and Martin-Rosset et al. (1990) presented significantly lower values of the apparent digestibility coefficient for crude fibre, NDF, ADF and ADL than we found in 
the pasture vegetation. We believe that this is due to good quality and appropriate nutrient composition as well as energy content of the pasture vegetation and that it closely relates to the digestibility of organic matter. Compared to organic nutrients, except for $\mathrm{Ca}$, the pasture vegetation provided relatively low apparent digestibility coefficients including the total ash. In the available literature, we found no results regarding the apparent digestibility of mineral substances for pasture vegetation.

The achieved results have confirmed our hypothesis that compared to the authors who studied nutrient digestibility in feeds processed by heat, the digestibility of individual nutrients contained in pasture vegetation, especially the digestibility of protein, was higher than stated by the cited authors.

With respect to the quality nourishment in horses, the low digestibility of pasture vegetation minerals demonstrates the need for their regular supplementation in the form of mineral feed during the pasture period.

\section{Acknowledgements}

This work was financially supported by the project NAZV QH 92265 "Optimization of breeding and veterinary care system for the critically endangered population of Old Kladruber horses".

\section{References}

Drogoul C, Poncet C, Tisserand, JI 2000: Feeding ground end pelleted hay rather than chopped hay to ponies. 1. Consequences for in vivo digestibility and rate of passage of digesta. Anim Feed Sci Technol 87: 117-130

Homolka P, Kudrna V, Pluhařová H 1995: Digestibility of dietary nutrients and energy in the Czech warmblooded horse. Živ Výr 40: 75-78

Martin-Rosset W, Doreau M, Boulot S, Miraglia N 1990: Influence of level of feeding and physiological state on diet digestibility in light and heavy breed horses. Liv Prod Sci 25: 257-264

Miraglia N, Bergerob D, Bassanob B, Tarantolab M, Ladettob G 1999: Studies of apparent digestibility in horses and the use of internal markers. Liv Prod Sci 60: 21-25

Miyaji M, Ueda K, Hata H, Kondo S 2011: Effects of quality and physical form of hay on mean retention time of digesta and total tract digestibility in horses. Anim Feed Sci Technol 165: 61-67

Miyaji M, Ueda K, Nakatsuji H, Tomioka T, Kobayashi Y, Hata H, Kondo S 2008: Mean retention time of digesta in the different segments of the equine hindgut. Anim Sci J 79: 89-96

Pearson RA, Archibald RF, Muirhead RH 2006: A comparison of the effect of forage type and level of feeding on the digestibility and gastrointestinal mean retention time of dry forages given to cattle, sheep, ponies and donkeys. Br J Nutr 95: 88-98

Peiretti PG, Meineri G, Miraglia N, Mucciarelli M, Bergero D 2006: Intake and apparent digestibility of hay plus concentrate diets determined in horses by the total collection of faeces and n-alkanes as internal markers. Liv Sci 100: $189-194$

Sales J, Janssens GPJ 2003: Acid-insoluble ash as a marker in digestibility studies: a review. J Anim Feed Sci 12: $383-401$

Varloud M, de Fombelle A, Goachet AG, Dtrogoul C, Julliand V 2004: Partial and total apparent digestibility of dietary carbohydrates in horses as affected by the diet. Anim Sci 79: 61-72

Vostrý L, Hofmanová B, Vostrá Vydrová H, Přibyl J, Majzlík I 2012: Estimation of genetic parameters for melanoma in the Old Kladruber horse. Czech J Anim Sci 57: 75-82

Zeyner A, Kretschmer E, Fuchs R, Kaske H, Hoffmann M 2003: Investigation on influence of exercise intensity on the digestibility of the feed in adult riding horses. Proc. $7^{\text {th }}$ ESVCN Conference, Hannover, p. 74 